\title{
Hepatic protein synthesis and morphological parameters in blood of rats under oxidative stress and action of feed additive "Butaselmevit-plus"
}

\author{
M. Ivankiv' ${ }^{1}$, N. Kachmar' ${ }^{1}$, O. Mazurak ${ }^{1}$, T. Martyshuk ${ }^{2}$ \\ ${ }^{1}$ Lviv National Agrarian University \\ Dublyany, Ukraine \\ ${ }^{2}$ Stepan Gzhytskyi National University of Veterinary Medicine and Biotechnologies \\ Lviv, Ukraine \\ E-mail: mtv27@ukr.net
}

Received 29.10.2019 Accepted 04.12.2019

\begin{abstract}
The intensive development of animal husbandry at the present stage requires new approaches to organizing the feeding of farm animals and the introduction of modern feed additives, which are not normally used purely as feed, but are deliberately added to feed or water to improve their quality, increase productivity and animal welfare. To prevent the development of oxidative stress in animals, we used the feed additive "Butaselmevit-plus", which in its composition contains the fruits of milk thistle, selenium, methionine and vitamins A, E and D3. The aim of the study was to investigate the effect of feed additive Butaselmevit-plus on blood morphological parameters and protein synthesis of rat liver under tetrachloromethane poisoning. For research, we used Wistar male rats, which were divided into three groups of 20 animals each. Control rats were intact. The first and second experimental group of rats were administered tetrachloromethane. Experimental intoxication in animals was performed by twice (after $48 \mathrm{~h}$ ) intragastric administration of tetrachloromethane at a dose of $0.1 \mathrm{ml}$ per $100 \mathrm{~g}$ of rat body weight in the form of a $50 \%$ oil solution. Experimental group R2 was fed a feed additive of Butaselmevit-plus for a dose of $0.1 \mathrm{~g}$ per $100 \mathrm{~g}$ of body weight together with the feed for experimental toxicosis for 30 days. On the basis of the conducted researches positive effect of feed additive "Butaselmevitplus" on the organism of rats, which were intoxicated with tetrachloromethane, is shown, which is shown by normalization of hematological parameters and protein synthesis of liver function. Restoration of hematopoietic function of bone marrow of rats by intoxication with tetrachloromethane is due to the fact that the feed additive "Butaselmevit-plus" contains in its composition fruits thistle, which have a high level of vitamins A and K, and trace elements, namely: Ferum, Cuprum and Cobalt that are directly involved in hematopoiesis. When feeding Butaselmevit-plus as feed supplement, the number of red blood cells in the blood of the second experimental group of rats was higher than that of the first experimental group, but the control values reached only on the 30th day of the experiment. When using the feed additive Butaselmevit-plus in rats under conditions of oxidative stress development, the leukocyte count decreased to the optimum level.
\end{abstract}

Key words: Oxidative stress; Butaselmevit-plus feed additive; Selenium; Vitamins; Methionine; Liver; Terachloromethane

\section{Introduction}

Reactive oxygen forms (hydrogen peroxide, superoxide anions, hydroxyl radicals, etc.) are products of cellular metabolism. At low concentrations, they affect the physiological cellular processes, while their increase can cause irreversible changes in the cellular structure of proteins, lipids and DNA. Increased reactive oxygen species have been shown to lead to cell necrosis, apoptosis, autophagy, inflammation, and impaired tissue regeneration. The shift in the balance between oxidants and antioxidants toward oxidants, characterized by a pathological increase in reactive oxygen species, is defined by the term "oxidative stress". Oxidative stress contributes to the progression of liver steatosis to steatohepatitis, fibrosis, and necrosis followed by the formation of cirrhosis (Gutyj et al., 2018; Grynevych et al., 2018; Sobolev et al., 2019; Prysiazhniuk et al., 2019; Gutyj et al., 2019). The effects of the increase in the intensity of sex can be explained by damage to membranes, including mitochondrial, which leads to the formation of giant mitochondria and accelerate cell apoptosis (Gutyj et al., 2016; Gutyj et al., 2017; Kysera et al., 2018; Holovakha et al., 2018; Gutyj et al., 2019). To enhance the immune and antioxidant status of animals due to liver toxicity, in recent years, new preparations and feed additives based on vegetable raw materials have been widely used (Cherkashina \& Petrenko, 2006; Skry 'pny 'k, 2007; Saba et al., 2010; Zhukova et al., 2016; Gutyj et al., 2017). For the prevention of immunodeficiency in animals caused by the negative impact of exogenous environmental factors, more promising phytopreparations: echinacea, fruits of magnolia, ginseng root. According to recent studies, the most promising immunostimulants are considered to be the fruits of milk thistle (Khariv et al., 2016; Khariv et al., 2017; Gutyj et al., 2019). Among the biologically active additives, the most common are selenium preparations. Of particular importance is now the study of the interaction of selenium with other trace elements, which are normalized in the diet, due to the increased technogenic impact on the animal body (Sobolev et al., 2017). The intensive development of animal husbandry at the present stage requires new approaches to organizing the feeding of farm animals and the introduction of modern feed additives, which are not normally used in pure form as feed, but are deliberately added to feed or water to improve their quality, increase productivity and animal welfare (Kotsumbas \& Hryniv, 2016).

To prevent the development of oxidative stress in animals, we used the feed additive "Butaselmevit-plus", which in its composition contains the fruits of milk thistle, selenium, methionine and vitamins A, E and D3.

Due to the presence of thistle spotted flavolignans of Silymarin group, vitamins, trace elements and other biologically active substances, its antioxidant, hepatoprotective and immunostimulatory pharmacological action is shown (Gutyj et al., 2019). 
It should be noted that methionine, which is part of the feed additive combines enzymatic and non-enzymatic systems of antioxidant protection of biological membranes of cells. It provides the conversion of neutral fats into phospholipids, which in turn stabilize subcellular membranes, providing antioxidant protection (Al-Badu et al., 2018). Selenium is important for the formation of proteins in the body. It supports normal liver function and strengthens the immune system by stimulating the production of antibodies, white blood cells, killer cells, macrophages and interferon (Sobolev et al., 2017). Vitamin A is a potent acceptor of peroxide radicals due to its ability to actively trap peroxide compounds. Vitamin $\mathrm{E}$ protects vitamin A from oxidation in both the intestines and tissues. Vitamin $\mathrm{E}$ stabilizes cell membranes and intracellular formations, a prerequisite for the protection of nuclear chromatin and DNA from the destructive action of free radicals (Lavryshyn et al., 2016). The aim of the study was to investigate the effect of feed additive Butaselmevit-plus on blood morphological parameters and protein synthesis of rat liver under conditions of tetrachloromethane poisoning.

\section{Material and Methods}

The experimental part of the work was performed on laboratory animals in the vivarium of the State Research Institute of Veterinary Drugs and Feed Additives. For research, we used Wistar male rats, which were divided into three groups of 20 animals each. Control rats were intact. The first and second experimental group of rats were administered tetrachloromethane. Experimental intoxication in animals was performed according to the method described by I.V. Matziopa in our modification, by double (after 48 h) intragastric administration of tetrachloromethane at a dose of $0.1 \mathrm{ml}$ per $100 \mathrm{~g}$ of body weight of the rat in the form of a $50 \%$ oil solution. Experimental group R2 was fed a feed additive of Butaselmevit-plus for a dose of $0.1 \mathrm{~g}$ per $100 \mathrm{~g}$ of body weight together with the feed for experimental toxicosis for 30 days. Blood for biochemical research was collected under ether anesthesia from the jugular vein for the fifth, tenth and twentieth, twenty-fifth and thirtieth days of the experiment.

The number of erythrocytes and leukocytes was counted on the grid of Goryaev counting chamber according to the conventional method. Blood hemoglobin level was determined by cyan-hemoglobin method using FEC-M by G.V. Dervis and A.G. Vorobiov method. Hematocrit was determined by centrifugation of the blood in micropipettes at $3000 \mathrm{rpm}$. According to the values of erythrocyte counts, blood hemoglobin level and hematocrit value, by the corresponding formulas, the following red blood index indices were calculated by mathematical calculations: average erythrocyte volume (MCV), mean hemoglobin content in erythrocyte (MSN) in erythrocyte (ICNS) (Vlizlo et al., 2012). Analysis of the research results was performed using the Statistica 6.0 software package. The probability of differences was estimated by Student's t-test. The results were considered plausible at $P \leq 0.05$.

\section{Results and Discussion}

In experimental poisoning with tetrachloromethane, a decrease in the number of erythrocytes in the blood of the experimental group R1 has been established since the 5th day of the experiment, where, accordingly, it decreased by $12.2 \%$. On the 10 th and 20th days of the experiment, the number of red blood cells in the blood of the first experimental group was the lowest, where relative to the control group it decreased by 22.9 and $26.5 \%$, respectively (Table 1 ).

Table 1. The number of erythrocytes in the blood of rats under the conditions of tetrachloromethane poisoning and the action of the feed additive "Butaselmevit-plus", $\mathrm{T} \mathrm{L}^{-1}$ (here and further the data presentred as $M \pm m ; n=20$ ).

\begin{tabular}{lcll}
\hline \multicolumn{1}{c}{ Day of research } & Control & Group of animals & R2 \\
5 & & $5.67 \pm 0.124 * *$ & $5.91 \pm 0.119^{*}$ \\
10 & & $4.98 \pm 0.099 * * *$ & $5.98 \pm 0.112^{*}$ \\
20 & $6.46 \pm 0.149$ & $4.75 \pm 0.123 * * *$ & $5.92 \pm 0.085^{*}$ \\
25 & & $5.04 \pm 0.111^{* * *}$ & $6.15 \pm 0.123$ \\
30 & & $5.11 \pm 0.097 * * *$ & $6.39 \pm 0.130$ \\
\hline
\end{tabular}

Here and further, level of probability:* $P<0.05$;** $P<0.025 ; * * * P<0.001$

When feeding Butaselmevit-plus feed supplement, the number of red blood cells in the blood of the second experimental group of rats was higher than that of the first experimental group, but the control values reached only on the 30th day of the experiment. The lowest number of red blood cells in the blood of the experimental group R2 was on the 5th day of the experiment, where, respectively, it was $5.91 \pm 0.119 \mathrm{~T} \mathrm{~L}^{-1}$. On the 20th day of the experiment, the number of erythrocytes in the blood of the second experimental group was higher than the experience of the first, but compared to the control group was lower by $8.4 \%$, respectively. In patients of rats of experimental group R1, the level of hemoglobin decreases, compared with the indicators of intact animals. Thus, on the 10th day of the experiment the level of hemoglobin in their blood decreased by $5.6 \%$, while on the 20 th day - by $8.7 \%$ relative to the indicators of the control group of rats. At the 25th and 30th days of the experiment, the level of hemoglobin increased slightly compared to the previous day, but remained low compared to the control group (Table 2).

Table 2. Level of hemoglobin in blood of rats under conditions of poisoning with tetrachloromethane and under the action of feed additive "Butaselmevit-plus", $\mathrm{g} \mathrm{L}^{-1}$

\begin{tabular}{llll}
\hline \multicolumn{1}{c}{ Day of research } & Control & Group of animals & R2 \\
5 & & $\mathbf{R 1}$ & $149.8 \pm 1.42$ \\
10 & & $150.2 \pm 1.85$ & $148.2 \pm 1.76$ \\
20 & $148.8 \pm 1.57$ & $140.4 \pm 2.05^{*}$ & $153.4 \pm 1.24$ \\
25 & & $135.8 \pm 0.97^{* * *}$ & $150.7 \pm 1.59$ \\
30 & & $140.7 \pm 1.11^{* *}$ & $150.4 \pm 1.24$ \\
\hline
\end{tabular}


An increase in the average erythrocyte volume (Table 3) and hemoglobin content in the erythrocyte (Table 4) showed a tendency to decrease the average hemoglobin concentration in the erythrocyte (Table 5). These changes are due to the effect of tetrachloromethane in the early stages of oxidative stress development, and it is likely that these changes are compensatory.

Table 3. The volume of erythrocyte in the blood of rats under the conditions of tetrachloromethane poisoning and the action of the feed additive "Butaselmevit-plus", $\mu \mathrm{m}^{3}$.

\begin{tabular}{llll}
\hline \multicolumn{1}{c}{ Day of research } & Group of animals & \multicolumn{1}{c}{$\mathbf{R 2}$} \\
5 & & $\mathbf{R 1}$ & $49.1 \pm 1.12^{*}$ \\
10 & & $51.9 \pm 1.18^{* *}$ & $50.0 \pm 1.18^{* *}$ \\
20 & & $61.6 \pm 1.22^{* * *}$ & $49.3 \pm 1.20^{*}$ \\
25 & $43.5 \pm 1.15$ & $66.5 \pm 1.18^{* * *}$ & $47.0 \pm 1.11$ \\
30 & & $62.1 \pm 1.15^{* * *}$ & $44.8 \pm 1.13$ \\
\hline
\end{tabular}

Table 4. The mass of hemoglobin in the erythrocyte in the blood of rats under the conditions of tetrachloromethane poisoning and the action of the feed additive "Butaselmevit-plus", pg ( $\pm m ; n=20)$.

\begin{tabular}{llll}
\hline \multicolumn{1}{c}{ Day of research } & Control & Group of animals & R2 \\
5 & & $\mathbf{R 1}$ & $25.35 \pm 1.25$ \\
10 & & $26.49 \pm 1.32$ & $24.78 \pm 1.40$ \\
20 & $23.03 \pm 1.50$ & $28.19 \pm 1.26^{*}$ & $25.91 \pm 1.16$ \\
25 & & $28.59 \pm 1.29^{*}$ & $24.50 \pm 1.41$ \\
30 & & $27.92 \pm 1.32^{*}$ & $23.54 \pm 1.38$ \\
\hline
\end{tabular}

On the 10th day of the experiment in the blood of rats of experimental group R1 an increase in hematocrit value up to $30.7 \pm 1.45$ $\mathrm{L} \mathrm{L}^{-1}$, whereas in the control group this indicator was $28.1 \pm 0.68 \mathrm{~L} \mathrm{~L}^{-1}$. Feeding of Butaselmevit-plus feed supplement to rats of the R2 experimental group during this period contributed to increase of hematocrit to $29.9 \pm 1.06 \mathrm{~L} \mathrm{~L}^{-1}$ (Table 6).

Table 5. Concentration of hemoglobin in erythrocyte in blood of rats under conditions of poisoning with tetrachloromethane and under the action of feed additive "Butaselmevit-plus", (\%).

\begin{tabular}{lccc}
\hline \multicolumn{1}{c}{ Day of research } & Control & Group of animals & R2 \\
5 & & $\mathbf{R 1}$ & $51.66 \pm 1.29$ \\
10 & & $45.73 \pm 1.32^{* *}$ & $49.57 \pm 1.30$ \\
12 & $53.00 \pm 1.34$ & $42.97 \pm 1.28^{* *}$ & $52.53 \pm 1.30$ \\
25 & & $44.95 \pm 1.33^{* *}$ & $52.15 \pm 1.34$ \\
30 & & $45.83 \pm 1.37^{* *}$ & $52.59 \pm 1.36$ \\
\hline
\end{tabular}

The increase in the number of leukocytes in the blood of rats of the experimental groups after the introduction of tetrachloromethane is the result of development in the body of inflammatory processes.

Table 6. The level of hematocrit in the blood of rats under the conditions of poisoning with tetrachloromethane and the action of the feed additive "Butaselmevit-plus", $\mathrm{L} \mathrm{L}^{-1}$.

\begin{tabular}{lccc}
\hline \multicolumn{1}{c}{ Day of research } & Gontrol & Group of animals & R2 \\
5 & & $29.4 \pm 1.24$ & $29.0 \pm 1.10$ \\
10 & & $30.7 \pm 1.45$ & $29.9 \pm 1.06$ \\
20 & $28.1 \pm 0.68$ & $31.6 \pm 1.34$ & $29.2 \pm 0.98$ \\
25 & & $31.3 \pm 1.30$ & $28.9 \pm 0.91$ \\
30 & & $30.9 \pm 1.46$ & $28.6 \pm 1.01$ \\
\hline
\end{tabular}

It was found that in the blood of rats of the first experimental group the number of leukocytes on the 10th day of the experiment increased by $24.9 \%$, whereas on the 20 th day - by $34.0 \%$ compared with intact rats. In the blood of rats of experimental group R2, the number of leukocytes in the specified periods of the experiment was higher by 9.6 and $7.6 \%$. On the 30th day of the experiment, the amount of the investigated indicator in the blood of the second experimental group reached physiological values (Table 7).

Table 7. The number of leukocytes in the blood of rats under the conditions of tetrachloromethane poisoning and the action of the feed additive "Butaselmevit-plus", $\mathrm{g} \mathrm{L}^{-1}$

\begin{tabular}{lccc}
\hline Day of research & Control & Groups of animals & $\mathbf{R 2}$ \\
5 & & $\mathbf{R 1}$ & $10.13 \pm 0.820$ \\
10 & & $10.74 \pm 0.731$ & $10.24 \pm 1.106$ \\
20 & $11.67 \pm 1.221$ & $10.05 \pm 1.310$ \\
25 & $9.34 \pm 0.760$ & $12.52 \pm 1.357 *$ & $9.87 \pm 1.754$ \\
30 & & $12.10 \pm 1.621^{*}$ & $9.45 \pm 1.052$ \\
\hline
\end{tabular}


In the study of protein synthesis of liver function, it was found that in the blood of rats of experimental groups R1 and R2 the level of total protein on the 5th day of the experiment fluctuated within $63.4 \pm 1.52$ and $64.2 \pm 1.63 \mathrm{~g} \mathrm{~L}^{-1}$, whereas in blood of the control group of rats, this indicator ranged from $65.2 \pm 1.80 \mathrm{~g} \mathrm{~L}^{-1}$. On the 10th day of the experiment, we observed a decrease in the total protein in the blood of the first experimental group by $7.7 \%$ (Table 8). The lowest level of the indicator, which was studied, was in the blood of the experimental group R1 on the 20th day of the experiment, where, accordingly, it was $59.6 \pm 1.84$ $\mathrm{g} \mathrm{L}^{-1}$, which was $8.6 \%$ lower than the control values. The level of total protein in the blood of rats of the second experimental group fluctuated within physiological values. It was highest on the 30th day of the experiment, where it was $65.4 \pm 1.56 \mathrm{~g} \mathrm{~L}{ }^{-1}$, respectively.

Table 8. The level of general protein in the blood of rats under the conditions of tetrachloromethane poisoning and the action of the feed additive "Butaselmevit-plus", $\mathrm{g} \mathrm{L}^{-1}$.

\begin{tabular}{lccc}
\hline \multicolumn{1}{c}{ Day of research } & Group of animals & $\mathbf{R 2}$ \\
5 & & $\mathbf{R 1}$ & $64.2 \pm 1.63$ \\
10 & & $63.4 \pm 1.52$ & $64.4 \pm 1.13$ \\
20 & $65.2 \pm 1.80$ & $59.2 \pm 1.95$ & $63.5 \pm 0.99$ \\
25 & & $60.4 \pm 1.75$ & $64.5 \pm 1.20$ \\
30 & & $62.1 \pm 1.95$ & $65.4 \pm 1.56$ \\
\hline
\end{tabular}

Table 9. The level of albumin in the blood of rats under the conditions of tetrachloromethane poisoning and the action of the feed additive "Butaselmevit-plus", $\mathrm{g} \mathrm{L}^{-1}$

\begin{tabular}{|c|c|c|c|}
\hline Dav of research & & Group of animals & \\
\hline Day of research & Control & R1 & $\mathbf{R 2}$ \\
\hline 5 & & $20.1 \pm 1.49$ & $20.9 \pm 1.55$ \\
\hline 10 & & $16.4 \pm 1.74 *$ & $21.1 \pm 1.62$ \\
\hline 20 & $22.7 \pm 1.26$ & $16.0 \pm 2.05^{*}$ & $20.9 \pm 1.75$ \\
\hline 25 & & $17.1 \pm 1.80 *$ & $22.4 \pm 1.85$ \\
\hline 30 & & $17.9 \pm 1.75$ & $22.8 \pm 1.92$ \\
\hline
\end{tabular}

Disruption of the protein synthesis of the rat liver during the development of oxidative stress was accompanied by impaired albumin to globulin in their blood. It was found that the decrease in total protein in the blood of the first experimental group of rats was accompanied by a simultaneous decrease in albumin levels and an increase in globulin levels. Thus, the level of albumin on the 20th day of the experiment in the blood of experimental group R1 decreased by $29.5 \%$ (Table 9), whereas the level of globulins increased by $2.6 \%$ (Table 10 ).

Table 10. The level of globulins in the blood of rats under the conditions of poisoning with tetrachloromethane and the action of the feed additive "Butaselmevit-plus", $\mathrm{g} \mathrm{L}^{-1}$

\begin{tabular}{lccc}
\hline \multicolumn{1}{c}{ Day of research } & Group of animals & $\mathbf{R 2}$ \\
5 & & $\mathbf{R 1}$ & $43.3 \pm 1.85$ \\
10 & & $43.3 \pm 2.15$ & $43.3 \pm 2.15$ \\
20 & $42.5 \pm 1.40$ & $43.8 \pm 2.52$ & $42.6 \pm 1.70$ \\
25 & & $43.6 \pm 1.98$ & $42.1 \pm 1.82$ \\
30 & & $43.3 \pm 2.10$ & $42.6 \pm 1.65$ \\
\hline
\end{tabular}

These studies indicate an albumin-globulin disproportion in the serum of diseased rats. As a result, the value of $A / G$ coefficient at 10 and 20 days of the experiment was $0.37 \pm 0.02$ versus $0.53 \pm 0.02$ in the control group of rats (Table 11). This magnitude of the factor indicates the inhibition of the protein synthesis of the rat liver.

Table 11. Ratio of A/G in the blood of rats under the conditions of tetrachloromethane poisoning and the action of the feed additive "Butaselmevit-plus".

\begin{tabular}{lccc}
\hline \multicolumn{1}{c}{ Day of research } & Group of animals & R2 \\
5 & Control & $\mathbf{R 1}$ & $0.48 \pm 0.03$ \\
10 & & $0.46 \pm 0.02^{*}$ & $0.49 \pm 0.02$ \\
20 & & $0.37 \pm 0.02^{* *}$ & $0.49 \pm 0.04$ \\
205 & $0.53 \pm 0.02$ & $0.37 \pm 0.03^{* *}$ & $0.53 \pm 0.02$ \\
30 & & $0.39 \pm 0.04 *$ & $0.54 \pm 0.02$ \\
\hline
\end{tabular}

While feeding of Butaselmevit-plus feed supplement to rats of the R2 experimental group increased the level of albumin in their blood throughout the experiment and slightly reduced the globulin fraction compared to rats that did not use the feed supplement. Within the physiological values was also the A/G factor. Restoration of hematopoietic function of bone marrow of rats by intoxication with tetrachloromethane is due to the fact that the feed additive "Butaselmevit-plus" contains in its composition fruits thistle, which have a high level of vitamins A and K, and trace elements, namely: Cuprum, Ferum and Cobalt, directly involved in hematopoiesis. Increased protein synthesis of liver function under the influence of feed additives is due to activation of metabolic processes in hepatocytes due to their oxygen supply, due to the normalization of red blood cells and hemoglobin content. 


\section{Conclusion}

We regiatered the positive effect of feed additive "Butaselmevit-plus" on the organism of rats, which were intoxicated with tetrachloromethane. It was manifested by normalization of hematological parameters and protein synthesis of liver function. Restoration of hematopoietic function of bone marrow of rats by intoxication with tetrachloromethane is due to the fact that the feed additive "Butaselmevit-plus" contains in its composition fruits thistle, which have high levels of vitamins A and $\mathrm{K}$, and trace elements, namely: Cuprum, Ferum, and Cobalt, directly involved in hematopoiesis.

\section{References}

Ahmad, M. K., Amani, S., \& Mahmood, R. (2011). Potassium bromate causes cell lysis and induces oxidative stress in humanerythrocytes. Environmental Toxicology, 29(2), 138-145. doi: 10.1002/tox.20780.

Al-Badu, L.-E., Smirnov, O., \& Kalachniuk, L. (2018). Dietetic ingredients of small animals suffering from obesity and their biological role. Scientific Messenger of Lviv National University of Veterinary Medicine and Biotechnologies, 20(92), 3-7. doi: $10.32718 /$ nvlvet9201.

Calabrese, E., Leonard, D., \& Zhao, X. (1996). Role of tissue repair in carbon tetrachloride hepatotoxicity in male and female Sprague-Dawley and Wistar rats. Int. J. Toxicol., 15, 62-69. doi: 10.3109/10915819609008707.

Chala, I.V., \& Rusak, V.S. (2016). Redox-potential and the state of peroxide oxidation of blood lipids in cows kept under ecologically unfavorable conditions. Scientific Messenger LNUVMBT named after S.Z. Gzhytskyj, 18, 2(66), 197-201. doi: 10.15421/nvlvet6640.

Cherkashina, D.V., \& Petrenko, A.Y. (2006). Hepatoprotective effect of fetal tissue cytosol and its thermostable fraction in rats with carbon tetrachloride-induced hepatitis. B. Exp. Biol. Med., 141(4), 544-547. doi: 10.1007/s10517-006-0216-y.

Grynevych, N., Sliusarenko, A., Dyman, T., Sliusarenko, S., Gutyj, B., Kukhtyn, M., Hunchak, V. Kushnir, V. (2018). Etiology and histopathological alterations in some body organs of juvenile rainbow trout Oncorhynchus mykiss (Walbaum, 1792) at nitrite poisoning. Ukrainian Journal of Ecology, 8(1), 402-408. doi: 10.15421/2018_228

Gutyi, B., Ostapiuk, A., Kachmar, N., Stadnytska, O., Sobolev, O., Binkevych, V., Petryshak, R., Petryshak, O., Kulyaba, O., Naumyuk, A., Nedashkivsky, V., Nedashkivska, N., Magrelo, N., Golodyuk, I., Nazaruk, N., \& Binkevych, O. (2019). The effect of cadmium loading on protein synthesis function and functional state of laying hens' liver. Ukrainian Journal of Ecology, 9(3), 222226.

Gutyj, B., Grymak, Y., Drach, M., Bilyk, O., Matsjuk, O., Magrelo, N., Zmiya, M., \& Katsaraba, O. (2017). The impact of endogenous intoxication on biochemical indicators of blood of pregnant cows. Regulatory Mechanisms in Biosystems, 8(3), 438-443. doi: $10.15421 / 021768$.

Gutyj, B., Grymak, Y., Hunchak, V., Mysak, A., Nazaruk, N., Brezvyn, O., Hariv, I., Shcherbatyy, A., Semeniv, B., Bushueva, I., Parchenko, V., Kaplaushenko, A. (2018). Preclinical searches of the preparation Thireomagnile. Ukrainian Journal of Ecology, 8(1), 688-695. doi: 10.15421/2018_267

Gutyj, B., Khariv, I., Binkevych, V., Binkevych, O., Levkivska, N., Levkivskyj, D., \& Vavrysevich, Y. (2017). Research on acute and chronic toxity of the experimental drug Amprolinsyl. Regulatory Mechanisms in Biosystems, 8(1), 41-45. doi: 10.15421/021708.

Gutyj, B., Leskiv, K., Shcherbatyy, A., Pritsak, V., Fedorovych, V., Fedorovych, O., Rusyn, V., \& Kolomiiets, I. (2017). The influence of Metisevit on biochemical and morphological indicators of blood of piglets under nitrate loading. Regulatory Mechanisms in Biosystems, 8(3), 427-432. doi: 10.15421/021766

Gutyj, B., Martyshchuk, T., Bushueva, I., Semeniv, B., Parchenko, V., Kaplaushenko, A., Magrelo, N., Hirkovyy, A., Musiy, L., \& Murska, S. (2017). Morphological and biochemical indicators of blood of rats poisoned by carbon tetrachloride and subject to action of liposomal preparation. Regulatory Mechanisms in Biosystems, 8(2), 304-309. doi: 10.15421/021748.

Gutyj, B., Nazaruk, N., Levkivska, A., Shcherbatyj, A., Sobolev, A., Vavrysevych, J., Hachak, Y., Bilyk, O., Vishchur, V., \& Guta, Z. (2017). The influence of nitrate and cadmium load on protein and nitric metabolism in young cattle. Ukrainian Journal of Ecology, 7(2), 9-13.

Gutyj, B., Paska, M., Levkivska, N., Pelenyo, R., Nazaruk, N., \& Guta, Z. (2016). Study of acute and chronic toxicity of 'injectable mevesel' investigational drug. Biological Bulletin of Bogdan Chmelnitskiy Melitopol State Pedagogical University, 6(2), $174-180$.

Gutyj, B., Stybel, V., Darmohray, L., Lavryshyn, Y., Turko, I., Hachak, Y., Shcherbatyy, A., Bushueva, I., Parchenko, V., Kaplaushenko, A., Krushelnytska, O. (2017). Prooxidant-antioxidant balance in the organism of bulls (young cattle) after using cadmium load. Ukrainian Journal of Ecology, 7(4), 589-596

Gutyj, B., Stybel, V., Hariv, I., Maksymovych, I., Buczek, K., Staniec, M., Milczak, A., Bushueva, I., Kulish, S., Shcherbyna, R., \& Samura, T. (2019). Influence Of Amprolinsile And Brovitacoccid On The Protein Synthesizing Function Of The Liver And Enzyme Activity In Turkey Blood Serum During Eimeria Invasion. Research Journal of Pharmaceutical, Biological and Chemical Sciences, 10(2), 723-729.

Holovakha, V. I., Piddubnyak, O. V., Bakhur, T. I., Vovkotrub, N. V., Antipov, A. A., Anfiorova, M. V., Gutyj, B. V., Slivinska, L. G., Kurdeko, O. P., \& Macynovich, A. O. (2018). Changes in erythrocytopoesis indices in dogs with babesiosis. Regulatory Mechanisms in Biosystems, 9(3), 379-383. doi:10.15421/021856

Khariv, I., Gutyj, B., Hunchak, V., Slobodyuk, N., Vynyarska, A., Sobolta, A., Todoriuk, V., Seniv, R. (2017b). The influence of brovitatoxide in conjunction with milk thistle fruits on the immune system of turkeys for eimeriozic invasion. Scientific Messenger LNUVMBT named after S.Z. Gzhytskyj, 19(73), 163-168. doi: 10.15421/nvlvet7334

Khariv, M., Gutyj, B., Butsyak, V., \& Khariv, I. (2016). Hematological indices of rat organisms under conditions of oxidative stress and liposomal preparation action. Biological Bulletin of Bogdan Chmelnitskiy Melitopol State Pedagogical University, 6(1), 276-289. doi: 10.15421/201615.

Khariv, M., Gutyj, B., Ohorodnyk, N., Vishchur, O., Khariv, I., Solovodzinska, I., Mudrak, D., Grymak, C., \& Bodnar, P. (2017a). Activity of the T- and B-system of the cell immunity of animals under conditions of oxidation stress and effects of the liposomal drug. Ukrainian Journal of Ecology, 7(4), 536-541. doi: 10.15421/2017_157.

Kotsumbas, H.I., \& Hryniv, M.I. (2016). The influence of feed additives on productivity hematological and immunological parameters of the broiler chicks blood. Scientific Messenger LNUVMBT named after S.Z. Gzhytskyj, 18, 3(70), 157-160. doi: $10.15421 /$ nvlvet7037.

Kysera, Ya.V., Storchak, Yu.G., \& Gutyj, B.V. (2018). Experimental study of immunoprophylactic anti-pneumococcal medicine and its immunogenic properties. Ukrainian Journal of Ecology, 8(1), 307-316 
Lavryshyn, Y.Y., Varkholyak, I.S., Martyschuk, T.V., Guta, Z.A., Ivankiv, L.B., Paladischuk, O.R., Murska, S.D., Gutyj, B.V., \& Gufriy, D.F. (2016). The biological significance of the antioxidant defense system of animals body. Scientific Messenger LNUVMBT named after S.Z. Gzhytskyj, 18, 2(66), 100-111. doi: 10.15421/nvlvet6622.

Lee, J.Y., Lee, J.H., \& Kim, H.J. (2004). The preventive inhibition of chondroitin sulfate against the CCI4-induced oxidative stress of subcellular level. Arch. Pharm. Res., 27(3), 340-345.

Martyshuk, T.V., Gutyj, B.V., \& Vishchur, O.I. (2016). Level of lipid peroxidation products in the blood of rats under the influence of oxidative stress and under the action of liposomal preparation of "Butaselmevit", Biological Bulletin of Bogdan Chmelnitskiy Melitopol State Pedagogical University, 6 (2), 22-27. doi: 10.15421/201631.

Petrukh, I.M., Simonov, M.R., \& Vlizlo, V.V. (2015). Mineralnyi homeostaz u koriv, khvorykh na ketoz, za likuvanni preparatom «remivital». Naukovyi visnyk LNU veterynarnoi medytsyny ta biotekhnolohii. Seriia: Veterynarni nauky, 17(2), $183-188$.

Prysiazhniuk, N., Grynevych, N., Slobodeniuk, O., Kuzmenko, O., Tarasenko, L., Bevz, O., Khomiak, O., Horchanok, A., Gutyj, B., Kulyaba, O., Sachuk, R., Boiko, O., \& Magrelo, N. (2019). Monitoring of morphological parameters of Cyprinidae liver. Ukrainian Journal of Ecology, 2019, 9(3), 162-167

Saba, A.B., Oyagbemi, A.A., \& Azeez, O.I. (2010). Amelioration of carbon tetrachloride-induced hepatotoxicity and haemotoxicity by aqueous leaf extract of Cnidoscolus aconitifolius in rats. Nig. J. Physiol. Sci., 25(2), 139-147.

Skry `pny `k, I.M. (2007). Gepatoprotetorni zasoby` v suchasnij gepatologiyi. Consilium Medicumllkraina, 1(5), 11-15 (in Ukrainian). Sobolev, O.I., Gutyj, B.V., Sobolieva, S.V., Shaposhnik, V.M., Sljusarenko, A.A., Stoyanovskyy, V.G., Kamratska, O.I., Karkach, P.M., Bilkevych, V.V., Stavetska, R.V., Babenko, O.I., Bushtruk, M.V., Starostenko, I.S., Klopenko, N.I., Korol'-Bezpala, L.P., \& Bezpalyi, I.F. (2019) Digestibility of nutrients by young geese for use of lithium in the composition of fodder. Ukrainian Journal of Ecology, 9(1), 1-6.

Sobolev, A., Gutyj, B., Grynevych, N., Bilkevych, V., \& Mashkin, Y. (2017). Enrichment of meat products with selenium by its introduction to mixed feed compounds for birds. Regulatory Mechanisms in Biosystems, 8(3), 417-422. doi: 10.15421/021764.

Vlizlo, V.V., Fedoruk, R.S., \& Raty`ch, I.B. (2012). Laboratorni metody` doslidzhen` u biologiyi, tvary`nny`cztvi ta vetery` narnij medy`cy 'ni : dovidny `k. L`viv : Spolom (in Ukrainian).

Zhukova, I.O., Svitlychna-Kulak, Yu.S., \& Longus, N.I. (2016). Correction of stateof antioxidant protection in dogs when poisoned byneoverm. Scientific Messenger LNUVMBT named after S.Z. Gzhytskyj, 18, 3(70), 95-99. doi: 10.15421/nvlvet7022.

\section{Citation:}

Ivankiv, M., Kachmar, N., Mazurak, O., Martyshuk, T. (2019). Hepatic protein synthesis and morphological parameters in blood of rats under oxidative stress and action of feed additive "Butaselmevit-plus". Ukrainian Journal of Ecology, 9(4), 628-633.

(cc) EY This work is licensed under a Creative Commons Attribution 4.0. License 